\title{
Application technology solar thermal power plant in Al-Kut
}

\author{
Svetlana Sheina*, Murtadha Muhsin, and Lidiya Girya \\ Don State Technical University, 1, Gagarin sq., Rostov-on-Don, 344010, Russia
}

\begin{abstract}
In this research, we study the operation and challenges of a renewable energy facility in the city of Kut, in central Iraq, which is common in Iraq, the electricity is generating from oil and gas which are harmful to the environment. In the article we have made a detailed study on power generation by relying on sunlight and the water of the Tigris River (the most famous river in Iraq). The article aims to develop detailed solutions to obtain energy without harming the environment by converting solar thermal energy into kinetic energy to generate the steam needed to rotate turbines during the day. And stored energy for use at night. The research shows the results of renewable energy evaluation and technology management in Iraq. To reduce the carbon dioxide emissions resulting from the combustion of fossil fuels to maintain a safe and clean environment. The world today has already begun to turn to this type of energy, and Iraq is one of the first countries in the Middle East, which has a good climate and record conditions for the success of renewable energy projects, technology renewable energy projects in Iraq is a must, given our lack of such important projects in the public interest.
\end{abstract}

\section{Introduction}

Renewable Energy: it is energy that is generated from natural resources, such as tides, sunlight, wind, rain, waves, and geothermal heat.

In the beginning we tried to do a detailed article about the construction of a project by make modification of installation a hydroelectric turbines to generate power by the Kut barrage, which is located in city centre. But through the investigation and calculation more information we found out the flow rate of water is not satisfied to rotate the turbines by good power of rotate due to more reasons such as the Al Kut dam, has 56 gates are distributed on the along of the barrage, the water head is low between the two sides of the dam because the Al Kut dam is located horizontally and not like the rest of the dams that descend in a form similar to waterfalls like the Mosul Dam, as example.[1,2]

\footnotetext{
${ }^{*}$ Corresponding author: rgsu-gsh@mail.ru
} 


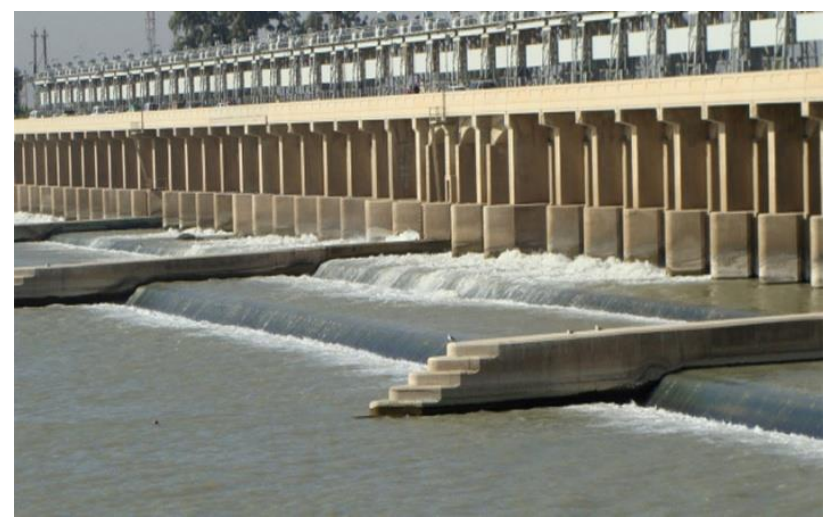

Fig. 1. Kut barrage

After those try we turn on to other side of green energy to get a organize a good project with more benefits to our city by using solar energy from the long daylights and high temperature of the sun, the idea is to be use mirrors for getting concentrating solar thermal power plants.

The reason which made me chose this type of plants to generate electric power is to contribute to spreading awareness in order to move towards renewable energy to preserve the environment and to reduce dependence on oil and gas resources in energy production. Iraq, from north to south in 2021, produces electric power using oil, and this has caused so big pollution, which has increased the spread of diseases such as cancer for most people. The time has come for a clean, high energy environment. As a researcher and civil engineer, I adopt this project for the sake of my country and the city where I live, in order to have a clean environment free of toxic emissions produced by the electric fields that operate with oil and gas. $81 \%$ of Iraq's electricity is generated by fossil fuel sources (thermal and gas). $19 \%$ is produced from renewable (hydro). Residential use competes with industrial and government consumption. While pre-war Baghdad was favoured for electricity distribution, the capital often uses programmed load-shedding during hot summer days to allocate four hours on, and then two hours off. The majority of Iraqi power plants are thermal plants that burn crude oil and were built in the 1970's and 1980's under Saddam Hussein. Nowadays, some of the power shortages are attributable to delays that oil tankers face in reaching and unloading at the southern Iraqi port city of Basra.[3]

Solar thermal power plants uses the sun as a heat source to rotate an engine and to produce heat energy. This process is associated with traditional forms of power generation based on fossil fuel combustion, which also depend on heat engines to convert thermal energy into electrical energy. The use of solar thermal power is not recently discovered up. Solar energy was first generated in Germany in 1907. In the United States, the sun was initially used as a heat source for power generation after the oil crisis of 1973. The first commercial station was established in the late 1980s in California [4].

Concentrating solar power plants (CSPPs) can prevent the emission of 7,600,000 (tons/year) of CO2 by 2020 , under an assumed capacity of $4000 \mathrm{MW}$. For example, a single $50 \mathrm{MW}$ parabolic trough power plant can cut annual heavy oil consumption by 30 million $\mathrm{L}$, and thus, eliminate 90,000 tons of $\mathrm{CO} 2$ emissions [5]. The increase in carbon fossil fuel prices after the global economic crisis in 2008 has escalated the need for sustainable energy, which is not subjected to price and supply fluctuations under political influences. Solar energy is considered to be an option for providing a low-carbon renewable source, and it is expected to become a competitive source of bulk power for peak and medium-peak loads by 2020 [6].. 


\subsection{General overview on Al-kut city}

Kut is centre of Wassit governorate, Wassit is located in eastern Iraq, on the border with Iran. The Abramabad border crossing in Wassit connects the two countries. Wassit shares internal boundaries with the governorates of Diyala, Baghdad, Babil, Qadissiya, Thi-Qar and Missan: kut is like other provinces which has climate, warm, disert lowlands, inclusive the alluvial plains and the deserts. In Kut has more seasons, summer, winter etc., with little transitional durations between them. Summer, which lasts from May to October, is depict by pure skies, extremely high temperatures, and low comprative humidity; no rain occurs from June through September. In Kut, July and August the daily degrees of temperature are around $\left(51^{\circ} \mathrm{C}\right)$. The daily temperatures ambit in summer is considerable.[7, 8]. Al kut needs to be provided by $1012 \mathrm{MW}$ [9] as maximum, the providing rate is fluctuated and affected by climate in summer and winter, providing of electric energy in winter its better than summer due to losses its little than the days are hot.

\section{Method statement of Concentrating Solar Power Plants}

The working principle of CSPPs is to initially convert solar radiation into thermal energy through a series of conversion processes, which ends with the generation of electrical output. The produced thermal energy may be converted using air, water, or oil as the working fluids. In solar chimney and solar vortex engine power plants, the working fluid used is air [10]. In concentrated solar power plants, the working fluid used is water (for direct systems) or oil (for indirect systems). The conversion of solar energy to thermal energy, and then to mechanical energy in the case of air, water, or oil, is typically achieved by using the Rankine cycle principles. Solar power generation plants can be based on four types of receivers: linear (parabolic troughs and Fresnel collectors) and focus point (solar towers and parabolic dish systems $[11,12]$. Several studies worldwide have shown that CSP plants are highly economical for generating solar electricity. These plants utilize concentrated solar radiation to achieve the grades necessary for processing thermal power plant dynamics or high heat. However, the applications of these plants are limited to land areas with high direct solar radiation [13]. Radiation from the sun can be converted into thermal and electrical energies. Solar thermal energy conversion can vary from low temperatures $\left(\mathrm{T}<100{ }^{\circ} \mathrm{C}\right)$ to medium temperatures $\left(100{ }^{\circ} \mathrm{C}<\mathrm{T}<400{ }^{\circ} \mathrm{C}\right)$, to high temperatures $\left(400{ }^{\circ} \mathrm{C}<\mathrm{T}<4000{ }^{\circ} \mathrm{C}\right)$, depending on the working medium temperature. Low-temperature solar energy conversion uses one flat collector with water and air. Medium-temperature conversion uses vacuum tube collectors, and collectors with concentrates. High-temperature conversion uses solar plants and CSP furnaces [14,15]. CSP stations use thermal energy from a heat storage tank, or gas as an energy source during the night, and on cloudy days $[16,17]$.

\subsection{Readiness of Iraq to get Solar thermal plant}

Iraq has a solarity ranging from $1800 \mathrm{kWh} / \mathrm{m} 2 /$ year to $2390 \mathrm{kWh} / \mathrm{m} 2 /$ year of direct normal radiation [18], which places the country in a highly promising status, and at the forefront of countries that produce electricity using solar energy. Table 1(data obtained using the software provided by Ref [19])It provides a comparison of solar radiation on horizontal, vertical and tilt planes optimally for some cities around the world where concentrated solar power plants have been installed, including many cities in Iraq, as mentioned in the Solar Electricity Guide (2016) [19]. 
Table 1. Solar irradiation on horizontal, vertical, and optimally inclined planes, and at optimal inclination for some cities where STPP plants have been installed, and some proposed cities in Iraq

\begin{tabular}{|c|c|c|c|c|c|}
\hline Location & Country & $\begin{array}{c}\text { Solar } \\
\text { irradiation on } \\
\text { horizontal } \\
\text { plan } \\
\text { (Wh/m2/year) } \\
\end{array}$ & $\begin{array}{c}\text { Solar } \\
\text { irradiation on } \\
\text { vertical plan } \\
\text { (Wh/m2/year) }\end{array}$ & $\begin{array}{c}\text { Solar } \\
\text { irradiation on } \\
\text { inclined plan } \\
\text { (Wh/m2/year) }\end{array}$ & $\begin{array}{c}\text { Optimal } \\
\text { inclination }\end{array}$ \\
\hline Phoenix & USA & 5280 & 3685.8 & 5895 & 57 \\
\hline Seville & Spain & 4868.3 & 3443.3 & 5410.8 & 53 \\
\hline Abu Dhabi & UAE & 5533.3 & 3186.6 & 5847.5 & 66 \\
\hline Musul & North Iraq & 4841.6 & 3319.1 & 5319.1 & 54 \\
\hline Karbala & Middle Iraq & 5104.16 & 3236.6 & 5492.5 & 57 \\
\hline Basra & South Iraq & 5035.8 & 3086.6 & 5276.66 & 60 \\
\hline
\end{tabular}

\section{Solar thermal power plants classification}

\subsection{The STP plants classification}

There are five main types of concentrating solar thermal power systems:

- Linear concentrating systems.

- Parabolic troughs.

- Linear Fresnel reflectors.

- Solar power towers.

- Solar dish/engines.

\subsubsection{Solar power towers}

This type which depended in our study. The solar power tower system utilities a large area of flat mirrors that track light of sun called heliostats to reflect light of sun and concentrate it at a receiver on top the tower. Sunlight can be concentrated more than 1,500 times. The water considers the main utility to get Some power towers as a heat transfer fluid. sophisticated designs experiment with molten nitre salt due to its excellent heat transfer and energy storage tanks. The capacity to store thermal energy allows the system to provide electricity at moment night or at cloudy weather.

\subsection{Technology and organization CSP in Iraq.}

\subsubsection{Potential of Solar Energy in republic of Iraq}

Iraq republic is known to have lengthy periods of daylight. On an yearly basis, Iraq gathers more than $3000 \mathrm{~h}$ of solar radiance in capital of Baghdad. The on and on solar intensity assorted between $416 \mathrm{~W} / \mathrm{m} 2$ in January, to $833 \mathrm{~W} / \mathrm{m} 2$ in June [20]. In fact, republic of Iraq outperforms Spain for the observed levels of sunshine [21]. The potential of solar technologies is considerably large, although its utilization is nearly nonexistent. Compared with other regions, the desert in western Iraq has the highest solar irradiance for electric power generation, compared to the annual global average horizontal surface irradiance of $170 \mathrm{~W} / \mathrm{m} 2$. The German Aerospace Center found that the deserts in Iraq produce a mean 
power density of $270 \mathrm{~W} / \mathrm{m} 2$ to $290 \mathrm{~W} / \mathrm{m} 2$, achieving a peak power density of 2310 $\mathrm{kWh} / \mathrm{m} 2 /$ year $[22,23]$. Approximately $31 \%$ of the surface of Iraq is composed of deserts. However, Iraq has the advantage of remaining one of the top current energy resources suppliers in the world, in terms of fossil fuels [24]. For this, the Iraqi authorities are not keen in utilizing solar energy. Thus, the importance of renewable energy is not being famed by the government and the people of Iraq. Therefore, the expanded of technologies that treasure to renewable energy in this zone are necessary, and will only be achieved through the initiatives of concerned individuals and non-governmental organizations, instead of official policies. During the last decade, the energy issue has expanded into a multidimensional question. Although Iraq has abundant fossil fuel sources, energy shortage has begun after the full-scale destruction of the country in 1991. Moreover, fossil fuel sources are limited, and they are expected to be used up in the coming hundred years. Amidst this scenario, solar energy is the only uninterrupted resource that will also help to reduce $\mathrm{CO}_{2}$ emissions from various fossil fuel and biofuel sources. Solar energy should be immediately considered, due to this climatic benefit, which can help to mitigate the effects of global warming [25].

\subsubsection{Solar power towers a model to use in Al-Kut}

As it mentioned that the electric of energy that the city is needs its $1012 \mathrm{MW}$ of energy to be always it will be provided to all the consumers, so this type of solar thermal plant provides the energy by convert the irradiation of sun as much as 1,500 times. The project will be distributed the residences by electric in day due to daylight and at night by the molten salt recerculated to heat exchanger to boil up the fluid heat which need to get rotate the turbine, then the generator rotating and generates energy. However this type is economic due to taking a little space on the ground and without heavy foundation to be supported. The high summer temperatures of about 51 degrees Celsius and the number of daylight hours of 14 hours helps to generate a large amount of steam that allows us to distribute it to more than one turbine, however to store a large count of thermal energy with molten salt to permit it to be used at night.

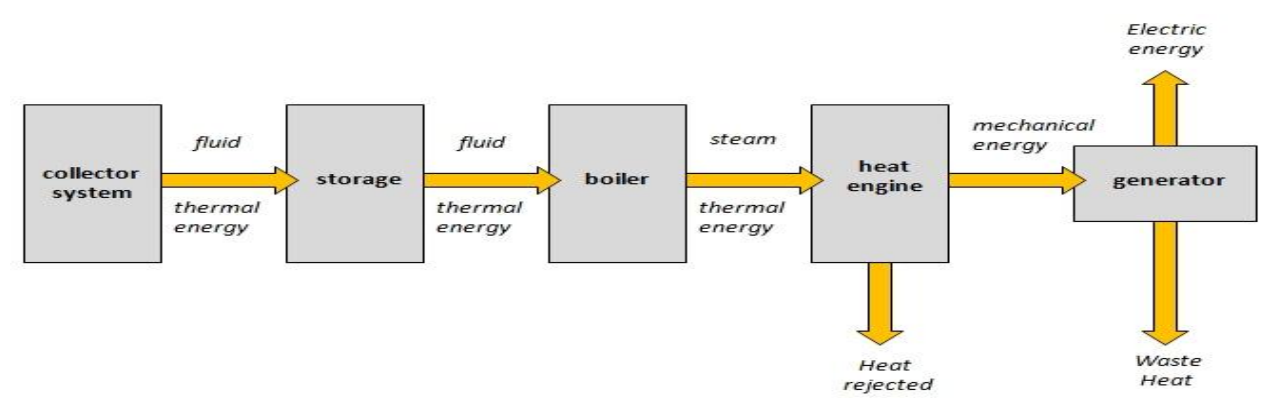

Scheme 1. Schematic of a generic solar thermal power system(Witmer) 


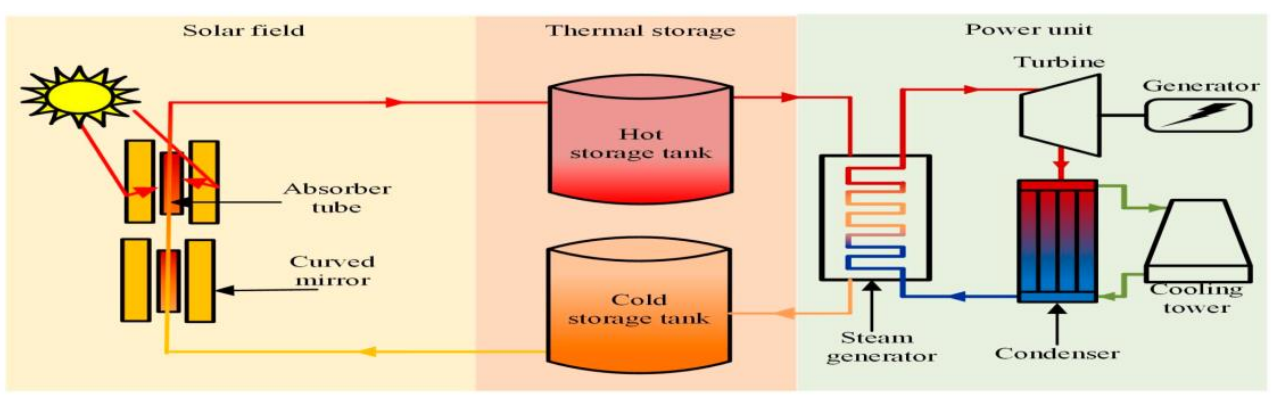

Scheme 2. Solar power thermal diagram [31]

\subsubsection{Challenges and restrictions of renewable energy planning in Iraq}

Discussions on initiatives to use renewable power sources in republic of Iraq present many restrictions and barriers that should be overcome before solar energy/wind utilization can be implemented. From the mark of view of the publishers, the subsequent are important marks that should be highlighted.

- Financial and economic constraints: These barriers focus on the high capital cost of renewable energy projects, with the failure of (or lack of) funding mechanisms, as well as on the mistaken belief that investments in projects represent a financial risk despite preserving the environment.

- Some banks and funding sources may not encourage loans and investments in emerging areas compared with projects involving conventional energy and support; hence, investments in renewable energy may not have the same kind of value, and they may not be economically attractive (cost-benefit analysis) compared to other investment opportunities.

- Limited policies, attractive private investments, and the lack of government resources allocated to them.

- A lack of public awareness regarding the available capabilities and the renewable energy systems that are used technically and economically.

- Difficulty in applying for a government funding system for renewable energy.

- Limited regional cooperation and coordination in the field of renewable energy projects and funding, as well as a dependence on foreign funding programs.

- The Iraqi market has limited experience and a lack of local expertise in the field of renewable energy resources in general, and for solar energy in particular.

- Accredited testing laboratories are insufficient, in terms of number and capability.

- The Iraqi government has enacted inadequate legislative laws that encourage the production and installation of monitoring devices used in solar energy systems.

- Prices for the production of electricity using common gas and oil, are frugal because of the price of energy-related products.

\section{Results}

As noted by numerous researchers [17,29] the deployment of CSP in a country requires four important factors, namely: High direct normal irradiation, Nearby water sources, Land 
area requirement., and Available transition. These four elements are essential, which makes finding suitable locations for CSP difficult. A good solar resource level is fundamental for deploying CSP plants. The hourly solar intensity in Iraq reaches $833 \mathrm{~W} / \mathrm{m} 2$ in June [20]. The water supply for energy generation and irrigation in Iraq is obtained from the Tigris and Euphrates Rivers. All of the rivers flowing through the north of Iraq are tributaries of Tigris. Both the Tigris and Euphrates originate from Turkey, with the Euphrates also passing through Syria. Water availability is certainly a limiting factor in Iraq, but not as much as it is frequently believed to be. For example, the amount of water used in a CSP plant is comparable with that used in the agricultural sector for the same land area. Table2 presents the water requirements for CSP technologies. Kut has river of Tigris.

Table 2. water requirements for CSP technologies.[20]

\begin{tabular}{|c|c|}
\hline Power technology & Water requirement \\
\hline Power tower & $2240-2800$ \\
\hline
\end{tabular}

A CSP plant requires flat land, which may also be a limitation. The dish and Fresnel systems are more modular and easier to adapt to an irregular terrain. Parabolic troughs and solar towers are more difficult to adapt to such terrain. An approximate land surface of 115 ha is required for each 50 MWe plant (Concentrating Solar Power Projects, 2016). This area per $50 \mathrm{MWe}$ is sufficiently large enough to prevent the shadowing effect caused by shade cast between solar collectors on a mounting area during the full sunny hours, which can reduce the efficiency of the system; it can also provide the space required for the conventional thermal components of a plant [26]. Such plants can be established in the central and southern parts of Iraq, such as Babylon, Diyala, Baghdad, Missan, Thi-Qar, and Basrah. However, the availability of water presents a challenge that should be considered. The multinational engineering and design firm Parsons Brinckerhoff (PB) reviewed the electrical network and other plans of Iraq, and identified potential areas for CPS development. They considered the distance-to-grid connection (less than $25 \mathrm{~km}$ ) the technical adequacy of the terrain, and financial and permission difficulties. PB proposed the establishment of a potential number of CSP plants, as indicated in Table 3[27].

Table 3. CSP plant potential in Iraq [27].

\begin{tabular}{|c|c|c|c|c|}
\hline Region & $\begin{array}{c}\text { Resource } \\
\text { (kWh/m2 })\end{array}$ & $\begin{array}{c}\text { Area for Plant } \\
\text { (ha) }\end{array}$ & $\begin{array}{c}\text { Possible No. } \\
\text { CPS Plant }\end{array}$ & $\begin{array}{c}\text { Installed } \\
\text { Power (MW) }\end{array}$ \\
\hline $\begin{array}{c}\text { Babylon, } \\
140 \mathrm{~km} \text { from } \\
\text { Kut }\end{array}$ & $2100-2200$ & 318 & 28 & 1400 \\
\hline $\begin{array}{c}\text { Basra, south } \\
\text { Iraq }\end{array}$ & $2100-2200$ & 203 & 18 & 900 \\
\hline $\begin{array}{c}\text { Anbar, west } \\
\text { Iraq }\end{array}$ & $2200-2300$ & 504 & 44 & 2900 \\
\hline
\end{tabular}

Solar resources exhibit inherent intermittence; in the long term, however, solar energy is reliable and can be predicted to a manageable level. To extend the operating hours of the CPS technology, and to secure a reliable peak load supply, support can be provided by TES systems, or by hybrid operation with a fossil fuel system. TES systems can extend the operation time by up to $100 \%$ solar share, although an economical trade-off has to be realized. A typical value is $7.5 \mathrm{~h}$ of thermal storage. To ensure a high level of CSP 
performance, periodic cleaning of the solar field mirrors is necessary. Iraq is a dusty area, and thus, frequent cleaning of glass surfaces with water, steam cleaners, or reverse vacuum cleaner systems is required. The frequency of these operations will depend on the plant location (i.e., proximity to desert areas, wind regimes, and rainfalls). Parabolic dishes can operate independently of electricity networks in remote sunny locations; hence, these networks are suitable for supplying power to people living in isolated and remote villages in the national grid.

\section{Discussion}

It is recommended to use parabolic troughs or solar towers in existing thermal plants. Solar power plants, using power towers, can operate independently of the grid in remote sunny locations, thus, these power plants also are suitable for supplying power to People who live in isolated, remote villages that are not connected to the national grid. However, The potential of solar energy to produce electricity has been found to be sufficient if used efficiently as an independent system and as an integrated system with thermal power plants. Cost analysis and Comparison suggests that 50MW CSP technology is economically feasible at 0.23 US cents / $\mathrm{kWh}$, When connected to a network without storage. Lack of good planning, judgment or initiatives by the authorities, restrictions and impediments are imposed on the development of renewable energy in Iraq.STP gives us thousands of energy with minimum cost and minimum base surface if comparison with other sources, as example, the ministry of electric has an activity in preparing, designing and supervising the installation of solar energy systems on the roofs of the buildings of the ministries and their departments, as the initiative began in the Ministry's building and some departments, and work continues to deliver and implement these systems, including:1- A solar power plant (P.V) with a capacity of (1MW) at the Ministry's headquarters $(250 \mathrm{KW}$ was commissioned as a first stage)2- A solar power plant (P.V) with a capacity of (130MW) at the University of Babylon. 3- A solar power plant (P.V) with a capacity of (100MW) at the Training and Development Department / Ministry of Electricity,(MOE) projects like those needs always maintenance and expensive prices.

\section{Conclusions}

This study presents an outlook on renewable energy sources in Iraq, particularly on solar energy. Given the climatic and geographical conditions in Iraq, installing CSP has been proven to be economically feasible in this study.

- Since the CSP is not generating by gas or oil, so its keeping the environment is clean, this kind of energy is free of $\mathrm{CO} 2$ emission.

- Projects of the renewable energy recently researched in Iraq, when its will be applied, this class will provide thousands of jobs.

- Enhancing Iraq's position among the countries of the world and support the trends cleaning the climate.

- Power supplying to rural areas which locating far from city centers, villages are not connected to the national grid of energy.

- Concentrating solar power plants (CSPPs) can prevent the emission of 7,600,000 (tons/year) of $\mathrm{CO}_{2}$, under an assumed capacity of $4000 \mathrm{MW}$. For example, a single $50 \mathrm{MW}$ parabolic trough power plant can cut annual heavy oil consumption by 30 million L, and thus, eliminate 90,000 tons of $\mathrm{CO}_{2}$ emissions. 
- Because of the devastating impact of fossil fuel consumption on the environment and continuous growth in global power demand, the development of alternative energy must be hot topic for many governments and energy stakeholders.

- There is an urgent need to explore alternative energy technologies and systems for sustainable development, improve the power generation capacity of renewable energy, and realize sustainable growth in power production capacity.

- When combined with thermal storage capacity, CSP plants are able to generate electricity during cloudy periods or for hours after sunset or before sunrise.

- One square mirror in the solar field produces $400 \mathrm{kWh}$ of electricity per year, avoids 12 tons of $\mathrm{CO}_{2}$ emission, and contributes to 2.5 tons savings of fossil fuels during 25 -year operation lifetime [30].

\section{References}

1. Iraqi Ministries of Environment, Water Resources and Municipalities and Public Works (2006). "Annex III: Main water control structures (dams and water diversions) and reservoirs". New Eden Master Plan for integrated water resources management in the marshlands areas. New Eden Group.

2. Sayigh, Yusif Abdalla (1978). The economies of the Arab world: development since 1945. London: Taylor \& Francis. p. 30. ISBN 978-0-85664-474-0.

3. Iraq, ministry of planning, table 17/16 A NUMBER OF ELECRICAL ENERGY PRODUCTION STATIONS,THE BRODUCED AMOUNT AND THE PERCENTAGE OF ACTUAL PARTICIPATION BY TYPE OF STATIONS IN $\begin{array}{lllll}\text { IRAQ EXCLUDING KURDISTAN REGION } & \text { FOR }\end{array}$ http://www.cosit.gov.iq/AAS2016/environment/env(42).htm

4. Poullikkas, A. Economic analysis of power generation from parabolic trough solar thermal plants for the Mediterranean region: A case study for the island of Cyprus. Renew. Sustain. Energy Rev. 2009, 13, 2474-2484. https://www.sciencedirect.com /science/article/abs/pii/S1364032109001294?via\%3Dihub

5. Stoddard, L.; Abiecunas, J.; O'Connell, R. Economic, Energy, and Environmental Benefits of Concentrating Solar Power in California; Subcontract Report NREL/SR550-39291; National Renewable Energy Laboratory: Golden, CO, USA, 2006.

6. Energy Information Administration. International Energy Outlook 2006; EIA: Washington, DC, USA, 2006.

7. "Weather longterm historical data Baghdad, Iraq". The Washington Post. 1999. Archived from the original on 29 November 2014.

8. Brugge, Roger. "World weather news, August 2011". Department of Meteorology, University of Reading. Archived from the original on 21 August 2016.

9. The table of the Ministry of Electricity, published on August 20, 2019, shows the rate of energy supply for each province with the required rate at peak time. Alsumaria News.

10. Mustafa, A.; Al-Kayiem, H.; Gilani, S. A survey on Performance enhancement of Solar Updraft Tower Power Plants. Int. J. Eng. Tech. Res. 2014, 7, 34-39

11. Jamal, M.; Abd Rahman, A.; Shamsuddin, A. Advance in the integration of solar thermal energy with conventional and non-conventional power plants. Renew. Sustain. Energy Rev. 2013, 20, 71-81. https:/linkinghub.elsevier.com/ retrieve/pii/S1364032112005692 
12. Manzolini, G.; Giostri, A.; Saccilotto, C.; Silva, P.; Macchi, E. Development of an innovative code for the design of thermodynamic solar power plants part A: Code description and test case. Renew. Energy 2011, 36, 1993-2003. https://www.sciencedirect.com/science/article/abs/pii/S0960148111000061?via\%3Dih $\mathrm{ub}$

13. Al-sakaf, O. Application possibilities of solar thermal power plants in Arab countries. Renew. $\quad$ Energy 1998, 4-9. https://linkinghub.elsevier.com/retrieve/pii/S0960148198000391

14. Pavlovi'c, T.; Cabri'c, B. ' Physics and Techniques of Solar Energy; GraDevinskaKnjiga: Belgrade, Serbia, 2007. (In Serbian)

15. Fernández-García, A.; Zarza, E.; Valenzuela, L.; Pérez, M. Parabolic-trough solar collectors and their applications. Renew. Sustain. Energy Rev. 2010, 14, 1695-1721. https://linkinghub.elsevier.com/retrieve/pii/S1364032110000675

16. Sharma, A. Comprehensive study of solar power in India and World. Renew. Sustain. Energy Rev. 2011, 15, 1767-1776. https://www.sciencedirect.com/science/article/ abs/pii/S1364032110004521?via\%3Dihub

17. Kaygusuz, K. Prospect of concentrating solar power in Turkey: The sustainable future. Renew. Sustain. Energy Rev. 2011, 15, 808-814.https://www.sciencedirect.com/ science/article/abs/pii/S1364032110003291?via\%3Dihub

18. 18. Burgermeister, J. Iraq Looks to Solar Energy to Help Rebuild its Economy. Renewable Energy World. Available online: https://www.renewableenergyworld.com/articles/2009/03/iraq-looks-to-solar-energytohelp-rebuild-its-economy.html (accessed on 10 January 2019).

19. Solar Electricity Handbook. Available online: https://solargis.com/maps-and-gisdata/download/iraq/ (accessed on 10 January 2019).

20. Kazem, H.; Chaichan, M. Status and future prospects of renewable energy in Iraq. Renew. Sustain. Energy Rev. 2012, 16, 6007-6012., https://www.sciencedirect.com/science/article/abs/pii/S1364032112002420?via\%3Dih $\mathrm{ub}$

21. Food and Agriculture Organization of the United Nation. Available online: http://www.fao.org/ag/agl/ aglw/aquastat/countries/iraq/index.stmS (accessed on 12 January 2018).

22. Feltrin, A.; Freundlich, A. Material considerations for terawatt level deployment of photovoltaics. Renew. Energy 2008, 33, 180-185., https://www.sciencedirect.com/science/article/abs/pii/S0960148107001437?via\%3Dih $\mathrm{ub}$

23. Sørensen, B. Renewable Energy: Its Physics, Engineering, Use, Environmental Impacts, Economy and Planning Aspects; Roskilde University: Roskilde, Denmark, 2004.

24. Abed, F.M.; Al-Douri, Y.; Al-Shahery, G. Review on the energy and renewable energy status in Iraq: The outlooks. Renew. Sustain. Energy Rev. 2014, 39, 816-827., https://www.sciencedirect.com/science/article/abs/pii/S136403211400478X?via\%3Dih $\mathrm{ub}$

25. Jacobson, M.Z.; Howarth, R.W.; Delucchi, M.A.; Scobie, S.R.; Barth, J.M.; Dvorak, M.J.; Klevze, M.; Katkhuda, H.; Miranda, B.; Chowdhury, N.A.; et al. Examining the feasibility of converting New York State's all-purpose energy infrastructure to one using wind, water, and sunlight. Energy Policy 2013, 57, 585-601., 
https://www.sciencedirect.com/science/article/abs/pii/S0301421513001213?via\%3Dih $\mathrm{ub}$

26. Шеина С.Г., Умнякова Н.П., Федяева П.В., Миненко Е.Н.Лучший Европейский опыт внедрения энергосберегающих технологий в жилищном фонде Российской Федерации/Жилищное строительство - 2020. №6 C. 29-34.URL: https://doi.org/10.31659/0044-4472-2020-6-29-34

27. Sheina, S.G., Girya, L.V., Vinogradova, E.V., Sobolevskiy, A. Methodology for a comprehensive analysis of the construction projects' accidents causes at various stages of their life cycle IOP Conference Series: Materials Science and Engineering - 2020. Vol. 913, Is. 4. - Article 042032. - (International Scientific Conference "Construction and Architecture: Theory and Practice of Innovative Development" (CATPID -2020) Part 1, 26-30 September 2020, Nalchik, Russian Federation). -URL: https://iopscience.iop.org/article/10.1088/1757-899X/913/4/042032

28. Svetlana Sheina, Natalya Tsopa, Formation the Construction Cost for Residential Buildings at the Design Stages//International Scientific Conference Energy Management of Municipal Facilities and Sustainable Energy Technologies EMMFT 2018 pp 224-235-URL: https://doi.org/10.1007/978-3-030-19868-8_23

29. Sharma, C.; Sharma, A.K.; Mullick, S.C.; Kandpal, T.C. Assessment of solar thermal power generation potential in India. Renew. Sustain. Energy Rev. 2015, 42, 902-912. https://www.sciencedirect.com/science/article/abs/pii/S1364032114008843?via\%3Dih $\mathrm{ub}$

30. The European Academies Science Advisory Council (EASAC). Concentrating Solar Power: Its Potential Contribution to a Sustainable Energy future. Available online: https://www.easac.eu/fileadmin/Reports/ Easac_CSP_Web-Final.pdf (accessed on 20 April 2018)

31. Belgasim, B.; Aldali, Y.; Abdunnabi, M.J.R.; Hashem, G.; Hossin, K. The potential of concentrating solar power (CSP) for electricity generation in Libya. Renew. Sustain. Energy Rev. 2018,90, 1-15. https://www.sciencedirect.com/science/ article/abs/pii/S1364032118301357?via\%3Dihub 